DOI 10.31558/2519-2949.2021.2.6

УДК 323.2

ORCID ID: https://orcid.org/0000-0001-5421-0271

Станіславенко Л. А., Донецький національний університет імені Василя Стуса

\title{
ПОЛІТИКА КОНСОЛІДАЦІЇ УКРАЇНСЬКОЇ ДЕРЖАВИ В УМОВАХ ТРАНСФОРМАЦЙНОЇ КРИЗИ
}

\begin{abstract}
У статті здійснено спробу обтрунтувати доцільність та практичну значущість формування комплексної багаторівневої політики консолідації української держави на основі об'єднуючих всі групи суспільства громадянсько-політичних цінностях.

Запропоновані висновки та індикатори консолідачії суспільства є частиною розробленої авторкою моделі формування та коригування політики консолідації держави в умовах системної кризи в Україні. Теоретичні міркування трунтуються на наукових текстах та дослідженнях Інституту соиіології НАН Украӥни, Інституту політичних і етнонаціональних досліджень НАН України ім. І.Ф. Кураса, матеріалах соціологічних опитувань. Визначено, щцо перспектива розвитку украӥнського суспільства полягає у комплексній державній програмі та активності громадянського сектору в контексті досягнення внутрішньої $і$ зовнішньої консолідації. Доведено, що украӥнський кейс транзиту демократії демонструє системність проблем економічного, інституиійного, політичного, соиіального, безпекового напрямів розвитку держави, які набувають ознак постійної трансформації та перетікання з однісї в іншу площини. Вказано, щзо з-поміж низки підходів до трактування категорії «консолідація», ї̈ функціональне значення полягає у спроможності бути одночасно і процесом, і результатом здійснення відповідної політики у державі. Потениіал розробки ефективної довгострокової програми розвитку суспільства виявлено у цінностях, щзо мають громадянсько-політичний характер. Визначено необхідність виведення з публічного дискурсу тем та дискусій щодо етнічно-національних иінностей, які призводять до конфронтації та розколу в українському суспільстві. Обтрунтовано, щчо заснована на иінностях української політичної (громадянської) нації, політика консолідації держави покликана завериити етап самоідентифікаиії українського суспільства та надати ицвілізаційної $і$ геополітичної суб'єктності державі Україна.
\end{abstract}

Ключові слова: політика консолідаиї̈ держави, ціннісний вимір консолідащії, трансформачійна криза, громадянсько-політичні цінності консолідащії суспільства.

Сучасний суспільно-політичний розвиток України характеризується домінуванням у суспільстві деконсолідаційних тенденцій та розбалансованістю ціннісно-нормативної системи. Революція Гідності та російська військова агресія проти України зрушили процес формування української політичної нації, становлення та розвитку громадянського суспільства. Цей етап консолідаціїадаптації завершився консенсусом суспільства щодо неможливості реставрації колишньої політичної системи, неприйнятності диктатури, обмеження свободи та знищення громадянського сектору в Україні. Нові геополітичні реалії та загострення низки внутрішніх проблем у подальші роки довели безперспективність несистемних, адаптивних сценаріїв вироблення державної політики, яка в основі своїй не грунтується на прагненні досягти внутрішньої та зовнішньої консолідації українського суспільства.

Мета статті - виходячи з розуміння стану сучасної політичної системи в Україні як такої, що перебуває в трансформаційній кризі, встановити індикатори суспільної консолідації та запропонувати модель формування політики консолідації держави в умовах трансформаційної кризи.

У науковому дискурсі категорія «консолідація» почала використовуватися в XX ст. у контексті вивчення національних процесів, зокрема, в поліетнічних суспільствах. Зокрема, аналізуючи процес формування європейських націй, відомий іспанський філософ і соціолог Х. Ортега-і-Гасет виділяв три етапи:

1) об’єднання найбільш лінгвістично і географічно близьких етнічних груп;

2) внутрішня консолідація;

3) міцна держава [3, с. 118].

(C) Станіславенко Л. А., 2021 
У 70 - 80-ті pp. ХХ ст. використання означеної категорії розширилося у зв'язку з розробкою «моделі демократичного транзиту» та виникненням так званої «третьої хвилі демократії» (С. Гантінгтон). Зокрема, американський політолог Ф. Шміттер запропонував автономну теоретикометодологічну основу «консолідології», яку він вважав самостійним напрямом політичної науки. Саму ж консолідацію вчений розглядав як вибір, що веде до формування правил гри та домовленостей у політиці, а ключовою дилемою консолідації - питання про набір інститутів, з якими політики можуть погодитися, а громадяни - підтримати [13, с. 24].

Українська політична наука виробила підхід, що базувався на поточних проблемах державотворення в Україні після розпаду СРСР. Так доктор філософських наук, професор М. Степико визначив, що процес трансформації українського суспільства з 1991 р. був зумовлений конфронтацією трьох ціннісних систем:

- нової системи, що «імпортувалася» 3 країн західної цивілізації разом з ринковими моделями економічної трансформації і розширенням торговельних та інвестиційних зв'язків між Сходом і Заходом;

- старої, «радянської» системи цінностей, настанов та поведінкових стереотипів, які і дотепер впливають на суспільну свідомість;

- цінностей традиційної національної культури, що швидко відроджується [8, с. 16].

Український політолог С. Стоєцький виділив, крім цього, геополітичне розташування території України, яка перебуває на розломі й у точках дотику кількох цивілізацій - і великих, і локальних [9, с. 272].

Етнічний, культурний, соціальний, економічний аспекти консолідації українського суспільства ставали предметом напрацьованого за роки незалежності вітчизняними науковцями - О. Рафальським [6], С. Пирожковим, Ю. Богуцьким, Е. Лібановою, О. Майбородою [9-10] та іншими дослідниками Інституту політичних і етнонаціональних досліджень ім. І. Ф. Кураса НАН України - масиву наукових текстів, монографій та національних доповідей. Проте, комплексна, багатоаспектна проблема консолідації держави, побудова ефективної моделі формування і реалізації політики консолідації, особливо в умовах гібридної війни та системної кризи, що циклічно трансформується, вивчена недостатньо. Тож враховуючи нагальну практичну значущість перелічених проблем, озвучена тема заслуговує окремого комплексного розгляду.

Отже, в широкому сенсі консолідацію розуміють як зміцнення, згуртування суспільства і всіх його компонентів. Проте виходячи 3 диференційованості суспільства та враховуючи різноманіття структур і об'єднань в ньому, логічно припустити, що упроцесі консолідації може відбуватися об'єднання конфронтуючих груп навколо політичних або етнічних лідерів чи проти них. Тож, консолідація суспільства можлива по кількох вісях, що часто межують або перетинаються.

3 точки зору політичної практики, консолідація - це процес об'єднання, зміцнення єдності й згуртованості соціальних і політичних сил (людей, соціальних груп, політичних партій і організацій тощо) з метою посилення боротьби за вирішення спільних завдань [5]. Це і процес, і одночасно результат цього процесу, що залежить від обраних методів і засобів, здатних його стимулювати.

Безпосереднім результатом консолідації суспільства слід вважати створення умов для зміцнення суверенітету і незалежності держави. Більш того, суспільна консолідація здатна активізувати вдосконалення організаційних форм і комунікації в системі відносин «особистість - суспільство нація - держава» [6, с. 81]. На думку вітчизняної дослідниці А. Санченко, є сенс розглядати консолідацію як своєрідний підсилювач існуючих в будь-якому суспільстві колективних смислів та ідеологем, які акумулюються задля покращення економічного стану, системи відносин у суспільстві, нації, державі тощо [7, с. 162]. У довготривалій перспективі консолідація дійсно виявляється у поширенні певної системи ідей та цінностей і має циклічний характер.

Авторка виходить з оцінки сучасного стану політичного буття України як такого, що можна охарактеризувати як системна криза. Спричинена деградацією більшості державних і суспільних інститутів, системна криза в Україні грунтується на комплексі чинників суспільно-політичного і макроекономічного гатунку. І окрім глибокої ціннісної, інформаційної, політичної дезорієнтації значної частини суспільства, нездатність держави керувати кризовими станами свого поступу призвела до втрати територіальної цілісності країни, поставила під питання державний суверенітет і зробила Україну вразливою щодо рішень міжнародних партнерів та зовнішньої інтервенції.

Трансформація хронічної інституційної кризи в економічну, соціальну, конституційну та інші площини, типова для українського суспільства низька довіра до інститутів державної влади, на думку авторки, є ознаками високого рівня деконсолідаційних процесів у державі, аудит і вирішення котрих $€$ найголовнішим завданням державного і громадянського секторів. 
Експерти стверджують, що до 2014 р. консолідація українського суспільства - за оцінками самих громадян України, - була на доволі низькому рівні - 1,5 бали [4, с. 35.]. Після 2014 р. каталізатором посилення консолідаційних процесів стали спільні прагнення дати відсіч російській збройній агресії, захистити суверенітет і незалежність держави, інтегруватися до європейських та євроатлантичних безпекових і економічних структур. Однак, така консолідація «проти», навідміну від об'єднання «задля»: добробуту, економічного процвітання тощо, не мала довготривалої перспективи для суспільства. Більш того, неспроможність суспільства і політичних еліт сприймати Росію як ключового стратегічного антагоніста України і до 2014 р., лакмусувала низку грунтовних труднощів у контексті слабкої або несформованої національної ідентичності.

В умовах демократії чи демократичного транзиту консолідація суспільства зумовлена ціннісним плюралізмом, а також спільністю мети, яка не грунтується довкола ситуативного об'єднання проти антагоніста. На думку авторів національної доповіді «Україна: шлях до консолідації суспільства», ці умови забезпечують суспільну консолідацію максимальною природністю, адже «вона стає доволі динамічною і розгорнутою, відповідає структурі суспільства та його розвитку», а процеси субординації та координації в ній $є$ збалансованими, відображаючи взаємодію держави й громадянського суспільства [10, с. 17]. Однак слід визнати, що на сучасному етапі проєкти консолідації українського суспільства як раз і зосереджені на антагоністичному ставленні до опонента, ворога чи групи ворогів.

Тож системна помилка консолідаційних процесів в Україні, на переконання авторки, виникає саме через спробу відтворення іiі у невірний спосіб, протиприродній порядок. Саме забезпечення спільного соціально-економічного інтересу, урахування потреб різних соціальних груп на основі диференціації соціально-економічного простору і високі макроекономічні показники поступу України (внутрішня консолідація) мають бути найважливішою, фундаментальною умовою формування моделі зовнішньої консолідації суспільства в умовах трансформаційних змін. Крім того, успіх консолідації на базовому рівні спроможний захистити суспільство від маніпулятивних практик створення штучної суспільної конфронтації довкола питань, які насправді нівелюються потужними позиціями країни на світовій мапі.

На думку вітчизняного дослідника проблем політичної консолідації В. Федоренка, у демократичній країні сенс суспільної консолідації подвійний: зовнішній криється в актуалізації ролі держави як історичного та геополітичного суб'єкта, внутрішній - досягається на підставі економічних індикаторів іiі розвитку, полягає у сприянні гідному життю і самореалізації всіх громадян [12, С. 179]. Політика консолідації держави розглядається авторкою як інструмент досягнення консенсусу, згоди суспільства щодо: оцінки свого минулого; адекватного сприйняття сучасних подій та явищ; перспективних напрямів розвитку у майбутньому. Тож на системній основі вона має об'єднати різні напрями політики держави та активності громадянського сектору.

3 огляду на багатоаспектність і багатовимірність консолідації як такої, авторкою запропоноване наступне тлумачення «політики консолідації держави»: це цілеспрямована та обумовлена ціннісно-мобілізуючою стратегією суспільства практична діяльність державних і суспільних інституцій, направлена на покрокову реалізацію комплексної програми зміцнення, об’єднання суспільства й усіх його компонентів задля досягнення внутрішньої і зовнішньої консолідації держави в цілому [1]. Слід звернути увагу на інтегральну роль ціннісного виміру політики консолідації держави.

Моніторинг громадської думки щодо тих чи інших суспільно-політичних та соціальногуманітарних процесів в Україні виявив: потенційна конфронтація українського суспільства закладена в цінностях, що мають етнічне забарвлення, історичну оцінку подій тощо. Наприклад, мовні пріоритети, Друга світова війна, герої національно-визвольних подій 1917-1921 рр., міфи тощо [11, с. 98]. Натомість, спроможність консолідувати суспільство виявлена у цінностях громадянсько-політичного характеру: зростання економічного добробуту, справедливі суди, мінімізація корупції, якісна освіта тощо.

Так удоповіді «Консолідація українського суспільства: шляхи, виклики, перспективи», підготовленій експертами й аналітиками Центру Разумкова в грудні 2016 р., виявлено такі думки громадян щодо перспектив консолідації українського суспільства і держави:

- подолання існуючих соціально-економічних проблем, підвищення добробуту більшості громадян (67\% опитаних);

- подолання корупції і притягнення корупціонерів до відповідальності (66\%);

- зміна влади в Україні, прихід до влади чесних, професійних, некорумпованих людей (51\%); 
- більш справедливий розподіл суспільних благ, зменшення розриву між статками багатих і бідних громадян (48\%);

- збільшення участі громадян у вирішенні соціально важливих проблем на державному та регіональному рівнях (29\%) [2, с. 25-26].

Відтак, сформована саме на парадигмі консолідуючих суспільство цінностях модель політики консолідації держави має потенціал до успіху. Не менш важливим представляється мораторій на використання в публічному дискурсі цінностей конфронтації. На думку авторки, повернення в публічний простір тем суспільного розколу може стати можливим тільки після завершення консолідації-ідентифікації українського суспільства.

Консолідація-ідентифікація як етап консолідації українського суспільства і водночас продукт, результат відповідної політики пропонується вимірювати за такими ключовими індикаторами: консенсус, примирення суспільства щодо історичної пам'яті; громадянська політична культура; сформована на громадянсько-політичному ціннісному кластері національна ідентичність, стійка до загроз регіоналізації; капітал лояльності як наслідок ефективної економічної та справедливої соціальної, гуманітарної, культурної політики держави; стабільно високий рівень легітимності державних та суспільних інституцій; геополітична суб'єктність держави.

Отже, український кейс транзиту демократії демонструє системність проблем економічного, інституційного, політичного, соціального, безпекового напрямів розвитку держави, які набувають ознак постійної трансформації та перетікання з однієї в іншу площини. Спроби імітації реформ, точкової боротьби з окремими проявами системної кризи послаблюють ступінь довіри суспільства до влади, а вкрай низькі показники соціально-економічного розвитку України продукують дискусії в суспільстві довкола цінностей розколу і конфронтації. Політика консолідації держави має базуватися на ціннісно-нормативній стратегії громадянсько-політичного кластеру цінностей суспільства. Досягнення внутрішньої консолідації українського суспільства на основі індикаторів зростання економічного добробуту, формування громадянської політичної культури, конкурентоспроможної національної освіти, культури тощо стануть підгрунтям для консолідації зовнішньої. А це, в свою чергу, надасть Україні, що перебуває у стані війни з Росією, геополітичної суб'єктності задля вирішення проблем захисту своїх національних інтересів і відновлення державного суверенітету.

\section{Бібліографічний список:}

1. Горбулін В. Ціннісні дилеми зовнішньої і внутрішньої ефективності.

URL: https://dt.ua/internal/cinnosti-suspilstva-i-gibridniy-mir-kriza-modeli-zahistu-246525_html

2. Консолідація українського суспільства: шляхи, виклики, перспективи. Інформаційно-аналітичні матеріали до Фахової дискусії 16 грудня 2016 р. К.:Центр Разумкова, 2016. 100 с.

3. Ортега-і-Гасет Х. Вибрані твори. К. : Основи, 1994. 424 с.

4. Петрушина Т. Соціокультурний потенціал інноваційного розвитку українського суспільства. Українське суспільство 1992-2013: соц. моніторинг. К.: Ін-т соціології НАН України, 2013. 72 с.

5. Пирожков С., Хамітов Н. Україна: від штучної та реальної конфронтації до консолідації. Релігія в Україні. 2017. URL: https://www.religion.in.ua/zmi/ukrainian_zmi/38160-ukrayina-vid-shtuchnoyi-ta-realnoyikonfrontaciyi-do-konsolidaciyi.html

6. Рафальський О. О. Консолідація українського суспільства: етнополітичний вимір. К.: Інститут політичних і етнонаціональних досліджень ім. І. Ф. Кураса НАН України, 2018. 400 с.

7. Санченко А. Процес національної консолідації в умовах відновлення незалежності української державності / А. Санченко // Українознавство. 2010. № 2. С. 160-163.

8. Степико М. Т. Українська ідентичність: феномен і засади формування: монографія. К.: НІСД, 2011. 336 с.

9. Україна як цивілізаційний суб'єкт історії та сучасності: національна доповідь. Ред. кол. С. І. Пирожков, В. А. Смолій, Г.В. Боряк, Я.В. Верменич, С.С. Дембіцький, О. М. Майборода, С.В. Стоєцький, Н.В. Хамітов, Л. Д. Якубова, О.В. Ясь. Інститут історії України НАН України. Київ: Ніка-Центр, 2020. 356 с.

10. Україна: шлях до консолідації суспільства: національна доповідь. Ред. кол.: С. І. Пирожков, Ю.П. Богуцький, Е. М. Лібанова, О. М. Майборода та ін.; Інститут політичних і етнонаціональних досліджень ім. І. Ф. Кураса НАН України. К.: НАН Украӥни, 2017. 336 с.

11. Українське суспільство 1992-2013. Стан та динаміка змін. Соціологічний моніторинг. За ред. д.ек.н. В. Ворони, д.соц.н. М. Шульги. К.: Інститут соціології НАН України, 2013. 566 с.

12. Федоренко В. Політична консолідація: концептуальне обгрунтування в сучасному науковому дискурсі (перспективи громад). Вісник Львівського університету. Серія філос-політолог. студії, вип. 14. Львів, 2017. C. $177-183$.

13. Шмиттер Ф. Размышления о гражданском обществе и консолидации демократии. Полис. 1996. № 5. C. 16-27. 


\section{References:}

1. Gorbulin V. Cinnisni dy`lemy`zovnishn`oyi i vnutrishn`oyi efekty`vnosti.

URL: https://dt.ua/internal/cinnosti-suspilstva-i-gibridniy-mir-kriza-modeli-zahistu-246525_html

2. Konsolidaciya ukrayins`kogo suspil`stva: shlyaxy`, vy`kly`ky`, perspekty`vy`. Informacijno-anality`chni materialy` do Faxovoyi dy`skusiyi 16 grudnya 2016 r. K.:Centr Razumkova, 2016. 100 s.

3. Ortega-i-Gaset X. Vy`brani tvory`. K. : Osnovy`, 1994. 424 s.

4. Petrushy`na T. Sociokul turny`j potencial innovacijnogo rozvy`tku ukrayins`kogo suspil`stva. Ukrayins`ke suspil`stvo 1992-2013: socz. monitory`ng. K.: In-t sociologiyi NAN Ukrayiny`, 2013. 72 s.

5. Py`rozhkov S., Xamitov N. Ukrayina: vid shtuchnoyi ta real`noyi konfrontaciyi do konsolidaciyi. Religiya v Ukrayini. 2017. URL: https://www.religion.in.ua/zmi/ukrainian_zmi/38160-ukrayina-vid-shtuchnoyi-ta-realnoyikonfrontaciyi-do-konsolidaciyi.html

6. Rafal`s`ky`j O. O. Konsolidaciya ukrayins`kogo suspil`stva: etnopolity`chny`j vy`mir. K.: Insty`tut polity`chny`x i etnonacional`ny`x doslidzhen` im. I. F. Kurasa NAN Ukrayiny`, 2018. 400 s.

7. Sanchenko A. Proces nacional noyi konsolidaciyi v umovax vidnovlennya nezalezhnosti ukrayins koyi derzhavnosti / A. Sanchenko // Ukrayinoznavstvo. 2010. \# 2. S. 160-163.

8. Stepy`ko M. T. Ukrayins`ka identy`chnist`: fenomen i zasady` formuvannya: monografiya. K.: NISD, 2011. $336 \mathrm{~s}$.

9. Ukrayina yak cy`vilizacijny `j sub'yekt istoriyi ta suchasnosti: nacional’na dopovid’. Red. kol. S. I. Py`rozhkov, V. A. Smoliy`, G.V. Boryak, Ya.V. Vermeny`ch, S.S. Dembicz`ky`y”, O. M. May 'boroda, S.V. Stoyecz ky`y”, N.V. Xamitov, L. D. Yakubova, O.V. Yas`. Insty`tut istoriyi Ukrayiny` NAN Ukrayiny`. Ky`yiv: Nika-Centr, 2020. $356 \mathrm{~s}$.

10. Ukrayina: shlyax do konsolidaciyi suspil`stva: nacional’na dopovid`. Red. kol.: S. I. Py`rozhkov, Yu.P. Bogucz`ky`j, E. M. Libanova, O. M. Majboroda ta in.; Insty`tut polity`chny`x i etnonacional`ny`x doslidzhen` im. I. F. Kurasa NAN Ukrayiny`. K.: NAN Ukrayiny’, 2017. 336 s.

11. Ukrayins`ke suspil`stvo 1992-2013. Stan ta dy`namika zmin. Sociologichny`j monitory`ng. Za red. D.ek.n. V. Vorony`, d.socz.n. M. Shul'gy`. K.: Insty`tut sociologiyi NAN Ukrayiny`, 2013. 566 s.

12. Fedorenko V. Polity`chna konsolidaciya: konceptual’ne obg `runtuvannya $v$ suchasnomu naukovomu dy`skursi (perspekty`vy`gromad). Visny`k L`vivs`kogo universy`tetu. Seriya filos-politolog. studiyi, vy`p. 14. L`viv, 2017. S. 177-183.

13. Spmitter F. Razmyshleniya o grazhdanskom obshchestve i konsolidacii demokratii. Polis. 1996. № 5. S. 16-27.

\section{Crisis \\ Stanislavenko L. A. State Consolidation Policy of Ukraine in the Conditions of Transformation}

The article attempts to substantiate the expediency and practical significance of forming a comprehensive multilevel state consolidation policy of Ukraine based on unifying all groups of society civic and political values.

The proposed conclusions and indicators of consolidation of society are part of the author's model of formation and adjustment the policy of consolidation of the state in systemic crisis in Ukraine. Theoretical considerations are based on scientific texts and studies of the Institute of Sociology of the National Academy of Sciences of Ukraine, the Institute of Political and Ethnonational Studies of the National Academy of Sciences of Ukraine by I.F. Kuras, materials of opinion polls. It is determined that the perspective of development of the Ukrainian society consists in the complex state program and activity of civil sector in the context to achieve internal and external consolidation. It grounded that the Ukrainian case of the transit of democracy demonstrates the systemic problems of economic, institutional, political, social, security areas of state development, which acquire signs of constant transformation and flow from one plane to another. It is stated that among several approaches to the interpretation of the category of "consolidation", its functional significance lies in the ability to be both a process and the result of the implementation of appropriate policies in the state. The potential for developing an effective long-term program for the development of society is revealed in the values that have a civic and political character. The need to remove from public discourse topics and discussions on ethnic and national values that lead to confrontation and division in Ukrainian society has been identified. Based on the values of the Ukrainian political (civil) nation, the policy of state consolidation is designed to complete the stage of selfidentification of Ukrainian society and give civilizational and geopolitical subjectivity to the state of Ukraine.

Keywords: state consolidation policy, value dimension of consolidation, transformation crisis, civic and political values of society consolidation. 